\title{
XLII. On the cosmogony of Moses, in answer to Dr. Pritchard
}

\section{F.E-S.}

To cite this article: F.E-S. (1816) XLII. On the cosmogony of Moses, in answer to Dr. Pritchard, Philosophical Magazine Series 1, 47:215, 179-182, DOI: 10.1080/14786441608638830

To link to this article: http://dx.doi.org/10.1080/14786441608638830

曲 Published online: 27 Jul 2009.

Submit your article to this journal ๘

Џll Article views: 2

Q View related articles ¿ 
somposed, and the nature as well as the mode of organization of the primitive matter of the globe will therety be elucidated; and we shall estract oxygen from a substance in which its presence is least expected. This fact will, besides, derote that the metals the oxides of which are reducible by fire, owe this cuality to as smaller dose of oxygen, which is at the same time the cause of their greater weight.

Juncker had already ascertained that at a very intense heat silver is converted into a fused oxide ; and Richter mentions the fact of a considerable quantity of silver which a modern alchemist had kept in the fire several years, being thereby transformed into a mass of fused oxide. M. Richter having obtained this mass, trier to reduce it, first by heat and afterwards by the usual reducers, but he was able to extract only a very small portion of metal.

Silver, on being organized, may also become an acidifiable combustible; for between an oxide and such a body the distance is not great : and if azote is hydrogenated into ammonia, and if tellurium and arsenic, by an inverse action, from metals become acidifiable combrstibles, silver may very well, on receiving caleric, without losing hydrogen, become a double super-combination of this principle, and constitute either an acidifiable combustible or the oxide of a different metal, more energetic, because it has more hydrogen, and because with precautions we may obtain it reduced. This will be the second artificial metal, and others will soon follow, which, like ammonia, will be decomyosable, because it will exist by composition, and in which caloric, favoured by a disposing affinity, may be substituted for the hydrogen of the new metallization, and allow the oxide of silver to be reduced, per se, into its metal : but hydrogen at a lesser heat might also be substituted for the water of the new metal, and thus present it to us reduced. How can we see oxide of silver resist reduction in the fire, without making such a phrnomenon the subject of the most serious meditation?

XLII. On the Cosmogony of Moses, in Answer to Dr. Pritehard. By F. E-s.

To Mr. Tilloch.

SIR, - I FEEL no inclination to involve Doctor Prichard in controversy; but as he has had the advantage of fully stating the grounds of his opinions, given in your Magazine, relative to the Mosaic cosmogony, it will, I presume, be allowed me briefy to examine whether he has succeeded in removing the objections against them indicated in my former letter. 
In the paper* which oceasioned my observations, Doctor Prichard, after having, as he imagined, exhibited a complete coincidence between the series of facts detailed in the first chapter of Genesis and those inferred from geological phænomena, remarks, that "if this coincidence is surprising in itself, it appears the more so when we compare the cosmogony of the Hehrews with the notions on this subject that prevailed among other nations of antiquity. We find invariably that all other speculations on thi, sulject are founded on some fanciful analogy with uatural processes that are daily observed." In his recent comminicationt, however, our attention is particularly directed to, and our surprise excited by, "the remarkable connexion discovered between the primitive histories of the most vemote nations on the earth and these documents embodied in. Genesis." It is added that, not only the Asiatic nations, lizut the Runic scalds of Iceland and Scandinavia, and the ancient priests of Mexico were equally in possession of the primative traditions;" and the latter certainly never obtained them from Jerusalem $t$. Other similar facts are adduced in support of the opinion that the early parts of Genesis are a compilation: but in maintaining it, Doctor Priehard does not "place the author of the Pentateuch in the rank of common compilers of bistorical fragments possessed merely of natural intelligence;" nor does he regart the supposed materials of the compilation, "in their origin as common historical testimonies." On this hypothesis I shall merely obseve, that if in relating events which no uninspired person could ever with certainty know, the wuthor of the Pentateuch had recourse to records and traditions of whatever character or antiquity, it could only be to supply the want of immediate inspiration. It seems, therefore, that to preserve consistency, either the hypothesis or the inspiration of Moses must be abandoned.

I now proceed to the points in discussion. In my former observations the word day is admitted to have been figuratively employed in Hebrew, as it has, I believe, in every language, to signify an indefinite portion of time; but I contended that in the six days creaiion it cannot be so understood; because, for no other discoverable purpose than to guard the term against a met..phorical interpretation, its meaning is there expressly confined to the duration of an evening and a morning, to the decay and the return of light, the limits of a natural day. This limitation, reiterated six times in terms as explicit as language can supply, causes no difficulty whatever to Doctor Prichard; " for," he remarks, "if we use the word day to signify a portion of

* Phil. Mag. No. 210, p. 285. † Ibid. No.211. † p. 112. time, 
time, and have occasion to allude to the beginning or end of the period designated, we always carry on the metaphor and adopt the correspouding terms." The truth of this position is chvious; but its application, instead of supporting the tropical sense contended for, affords an additional objection against it. In the day and night of Brama, the duration of the respective portions, the preceding and following twilight, the day, and the night, are all chronological periods; and a distinct notion is conveyed in properly sustained figurative language of the relative time of the exertion of Brama, when it is said, "At the close of his night, having long reposed, he wakes, and awaking exerts intellect." Had the morning and the evening been thus used in Genesis, to mark precerlence or sulssequence of different acts of creation in the same day; had it been said, The sun was made in the morning, the moon in the evening of the fourth dav, the language would with equal propriety have borne a literal or figurative interpretation. But it is remarkable, that neither the morning nor the evening is once alluded to for any such purpose: the acts of each day are enumerated, and the day itself is said to consist of an evening and a morning. This being so, if day be understood figuratively, there loes not appear to have been the slightest "occasion to allude to the begimming or end of the period designated' by it ; since no other information would be conveyed by the supposed allusions, than that an indefinite period was compesed of a metainorical evening and morning; or, in other words, that one indefinite period conssisted of two indefinite periods. I do not, however, pretend to appreciate the value of this information, estimated "according to the genius of Hebrew literature."

The other, and more weighty objection,-that it does not appear that the Hebrew people ever understood the six days of the creation as equivalent to so many indefinite periods, - seems insplicitly admitted by the remark, that had Noses read a lecture on greology to " the shepherds of Goshen, and told them what space of time each oceanic deposit occupied, and by what organic remains it is to be recognised, he would have spent his time to little purpose." Moses, however, told " the shepherds of Goshen" many things quite as difficult to comprehend as that each epoch of the creation had occupied an extensive period: nor does it seem at all easier to conceive creation the work of six days than of as many thousand years. With respect to successive oceanic deposits, each characterized by peculiar organic remains, no trace of such a series of events is discoverable in the Mosaic account. On the contrary, in that narrative, the waters retire previous to the existence of animated beings, and never. again cover the earth until the days of Noah; and the work M 3 
of creation is represented as simply progressive, which is little consonant with a series of creations and extinctions of whole races antecedent to the formation of man. Could these apparently irreconcilable discordancies be overlooked, still Doctor Prichard's parallel between the facts detailed in Genesis and those inferred from geological olservation wou'd fail. According to the sense in which the twentieth and two following verses of the first chapter of Genesis have hitherto been generally understood, all the inhabitants of the waters wete called into existence on the fifth day; while geological inference places the orders of testacea and zoophytes in the third; that is, in a period when, according to Moses, nothing animate was created. It is true, Doctor Prichard thinks their deficiency in loco-notion sufficient to excluie them from the tifth day's creation But be:ides that this criticism may be suspected of over refinement, it is to be observed thit, if they be excluded from that day, it is alsolutely certain that Moses has assigned them no other. Whon, therefore, zoophytes for their analogy to vegetables, and testacea without participating in that analogy, are removed from the fifth to the third day, and we are afterwards called upon to admire the coincirlence of the series of the facts detailed in Genesis with those inferred from geologicai phæummena, Doctor Prichard seems to forget that the coincidence is effected by his placing two orders of animated beings where Moses never placed them.

$$
\begin{array}{r}
\text { I am, sir, Your very obedient servant, } \\
\text { Bath, March 10, 1816. F- } \quad \text {-s. }
\end{array}
$$

P.S.- The conjecture thrown out at the close of my former letter has no higher pretension than a simple possibility. In making it, I was perfectly aware of the oljection which Doctor P., observes may be drawn from physical considerations set forth (not in the "Systeme de la Nature," but) in Laplace's Exposition du Système du Monde.

XLIII. Observations on the late excessive cold Weather. Byj WM. SKRIMSHIRE, Esq. of Wisbech.

$$
\text { To Mr. Tilloch. }
$$

$s_{\text {R }},-I_{N}$ consequence of the public solicitation of your valua. the correspondent Mr. ' $T$. Forster, as well as for the information of the other readers of your useful Magazine, I am induced to sent the following observations respecting the late intense cold as cxperienced in this part of the kingrlom. 